\title{
ILLINOIS STATE GEOLOGICAL SURVEY RADIOCARBON DATES IX
}

\section{CHAO-LI LIU, KERRY M RILEY, and DENNIS D COLEMAN}

Illinois State Geological Survey, Champaign, Illinois 61820

The following list contains samples of geologic interest that were processed from June 1980 through March 1983 at the Illinois State Geological Survey (ISGS) Radiocarbon Dating Laboratory. The benzene liquid scintillation technique was used following laboratory procedures previously reported by Coleman $(1973,1974)$.

All ages were calculated on the basis of a ${ }^{14} \mathrm{C}$ half-life of $5568 \mathrm{yr}$, using the NBS oxalic acid standard as reference. Errors $(1 \sigma)$ reported account only for uncertainties in activity measurements of the sample, standard, and backgrounds. Assignment of modern and minimum ages is based on the $3 \sigma$ criteria. Barry W Fisher assisted in sample preparation.

Lake Michigan Shoreline, Greater Chicago Area

Illinois

\section{Lake Michigan N Shore Channel, Bowmanville series}

Samples from Cook Co, within city limit of Chicago $\left(41^{\circ} 58^{\prime}\right.$ to $42^{\circ} 04^{\prime}$ N, $87^{\circ} 41^{\prime} \mathrm{W}$ ). Coll 1910 to 1914 by F C Baker (1920); subm by A K Hansel and Charles Collinson, ISGS.

ISGS-961. Station 9, P96, 244 to $279 \mathrm{~cm}$ depth

Shell from coarse sand layer.

ISGS-928. Station 9, P58, 279 to $292 \mathrm{~cm}$ depth

Wood from peaty zone.

ISGS-953. Station 27, P66

Wood from silt zone, $6.7 \mathrm{~m}$ thick.

ISGS-959. Station 16, P75 \& P148

$$
\begin{array}{r}
\mathbf{4 5 5 0} \pm \mathbf{7 0} \\
\delta^{13} C=-4.6 \% 0
\end{array}
$$

$5580 \pm 70$

$\delta^{13} C=-27.0 \%$

$$
5420 \pm 70
$$

$\delta^{13} C=-26.7 \%$

$$
\begin{array}{r}
4690 \pm 90 \\
\delta^{13} C=-3.9 \%
\end{array}
$$

Shell from gravel and sand layer overlain and underlain by silt.

General Comment (AKH): dates indicate that Bowmanville deposits are middle Holocene and record postglacial Nipissing transgression rather than low water phase of Lake Chicago as postulated by Baker.

\section{Lake Michigan N Shore Channel, Stations 33 and 37 series}

Samples from Cook Co, within city limit of Chicago $\left(41^{\circ} 58^{\prime}\right.$ to $42^{\circ} 04^{\prime}$ N, $87^{\circ} 41^{\prime} \mathrm{W}$ ). Coll 1910 to 1914 by F C Baker; subm by A K Hansel and Charles Collinson. 
ISGS-927. Station 37, P64, 70 to $278 \mathrm{~cm}$ depth

Pine cones from silt zone interstratified with sand.

ISGS-950. Station 33, P62, 305 to $307 \mathrm{~cm}$ depth

Wood from silt layer.

ISGS-984. Station 33, P60

Wood from sand layer, $0.3 \mathrm{~cm}$ thick.

General Comment (AKH): range of dates and stratigraphy indicate that deposition at this locality probably was alluvial and that lake level was below $184 \mathrm{~m}$ (Toleston and Main Algonquin) level between 11,000 and $8600 \mathrm{BP}$.

\section{Lake Michigan, N Shore Channel, lakeshore series}

Samples from Cook Co, within city limit of Chicago $\left(41^{\circ} 58^{\prime}\right.$ to $42^{\circ} 04^{\prime}$ $\mathrm{N}, 87^{\circ} 41^{\prime} \mathrm{W}$ ). Coll 1910 to 1914 by F C Baker; subm by A K Hansel and Charles Collinson.

ISGS-943. Station 62, P63

Wood from sand layer.

\section{ISGS-957. Station 63, P47}

Wood from sand layer.

$$
\begin{array}{r}
10,180 \pm 180 \\
\delta^{13} C=-26.1 \% 0
\end{array}
$$

$$
11,370 \pm 150
$$$$
\delta^{13} C=-26.5 \%
$$

General Comment (AKH): location of these samples with respect to former shorelines is uncertain.

\section{Rose Hill spit series}

Samples from Cook Co, within city limit of Chicago $\left(40^{\circ} 03^{\prime} 55^{\prime \prime} \mathrm{N}, 87^{\circ}\right.$ $\left.40^{\prime} 33^{\prime \prime} \mathrm{W}\right)$. From sand pile dredged from pit in Rosehill Cemetery. Coll 1982 by L R Follmer and A K Hansel; subm by A K Hansel.

\section{ISGS-985. AKH-2-82}

Driftwood from distal part of Rose Hill spit.

\section{ISGS-1097. AKH-1-82}

Driftwood from distal part of Rose Hill spit.

$$
\begin{array}{r}
11,610 \pm 70 \\
\delta^{13} C=-26.8 \%
\end{array}
$$

$$
11,000 \pm 80
$$$$
\delta^{13} C=-26.3 \%
$$

General Comment (AKH): dates indicate that Rose Hill spit, extension of Calumet shoreline $(189 \mathrm{~m}$ alt $)$ of Lake Chicago, is post-Two Creeks in age.

\section{ISGS-960. Palos Hills}

$6280 \pm 70$

$$
\delta^{13} \mathrm{C}=-28.0 \%
$$

Peat from Cook Co, at W edge of Palos Hills City limits $\left(41^{\circ} 41^{\prime} 37^{\prime \prime} \mathrm{N}\right.$, $87^{\circ} 50^{\prime} 20^{\prime \prime} \mathrm{W}$ ) from peat layer ca $46 \mathrm{~cm}$ thick overlying clay. Coll 1971 by 
A K Hansel; subm by Charles Collinson and A K Hansel. Comment (AKH): peat deposition in outlet channel documents low water phase between Calumet and Nipissing phases of Great Lakes.

\section{ISGS-970. Ogden ditch, P88}

$$
\begin{array}{r}
4640 \pm 80 \\
\delta^{13} C=-1.6^{0} \% o
\end{array}
$$

Shell from Cook Co, $2.4 \mathrm{~km} \mathrm{~N}$ and $0.8 \mathrm{~km} \mathrm{~W}$ of Chicago Midway Airport $\left(41^{\circ} 47^{\prime} 57^{\prime \prime} \mathrm{N}, 87^{\circ} 46^{\prime} 20^{\prime \prime} \mathrm{W}\right)$, from silt zone containing Unios in upper part. Coll 1910 to 1914 by F C Baker; subm by A K Hansel and Charles Collinson. Comment (AKH): date is consistent with ISGS-959, -961 on pelecypod shells from $\mathrm{N}$ Shore Channel and documents Nipissing phase of Great Lakes.

\section{ISGS-987. NE Park, Evanston}

$$
\begin{array}{r}
4670 \pm 180 \\
\delta^{13} C=-30.1 \% 0
\end{array}
$$

Buried soil from Cook Co, within city limit of Evanston $\left(42^{\circ} 03^{\prime} 55^{\prime \prime} \mathrm{N}\right.$, $87^{\circ} 40^{\prime} 33^{\prime \prime} \mathrm{W}$ ), from silt and fine sand zone. Coll 1982 and subm by A K Hansel. Comment (AKH): date limits Nipissing transgression to alt of $183 \mathrm{~m}$ to after $4970 \pm 180 \mathrm{BP}$.

\section{Waukegan Marsh series}

Peat and muck from Lake Co, within city limit of Waukegan $\left(42^{\circ} 23^{\prime}\right.$ $06^{\prime \prime} \mathrm{N}, 87^{\circ} 51^{\prime} 11^{\prime \prime} \mathrm{W}$ ), from organic silt zone. Coll 1982 L R Follmer; subm by A K Hansel.

\section{ISGS-1007. AKH-4-82}

From 1.3 to $1.4 \mathrm{~m}$ below surface.

\section{ISGS-997. AKH-5-82}

$$
\begin{array}{r}
\mathbf{3 7 3 0} \pm \mathbf{8 0} \\
\delta^{13} C=-28.2 \%
\end{array}
$$

From 1.8 to $1.99 \mathrm{~m}$ below surface.

General Comment (AKH): older date limits onset of accumulation of organic sediment in depression on Glenwood Lake Chicago plain. Younger date may be erroneous because site is overlain by fill and roadbed.

Wisconsin

\section{ISGS-999. AKH-6-82, Barnes Creek}

$5420 \pm 150$

$$
\delta^{13} \mathrm{C}=-28.2 \%
$$

Wood from Kenosha Co, $3.3 \mathrm{~km} \mathrm{~S}$ of Kenosha $\left(42^{\circ} 31^{\prime} 52^{\prime \prime} \mathrm{N}, 87^{\circ} 48\right.$, $50^{\prime \prime} \mathrm{W}$ ), from organic clayey silt zone. Coll 1982 by A K Hansel and Charles Collinson; subm by A K Hansel. Comment (AKH): date is max for nearshore sand body at Barnes Creek.

\section{St Francis power plant series}

Samples from Milwaukee Co, S of power plant, within city limit of St Francis, along Lake Michigan shoreline ( $42^{\circ} 58^{\prime} 02^{\prime \prime} \mathrm{N}, 87^{\circ} 50^{\prime} 48^{\prime \prime} \mathrm{W}$ ). Coll 1982 and subm by A K Hansel. 
ISGS-1023. AKH-8

$$
\begin{array}{r}
\mathbf{3 7 , 8 0 0} \pm \mathbf{1 1 0 0} \\
\delta^{13} C=-29.6 \% 0
\end{array}
$$

Carbonized wood from top of sand and gravel sequence under $4 \mathrm{~m}$ of Wadsworth till.

\section{ISGS-1025. AKH-7}

Wood peat from base of Haeger till.

\section{ISGS-1106. AKH-9}

$$
\begin{array}{r}
>\mathbf{4 2 , 0 0 0} \\
\delta^{13} C=-28.9 \% \text { o }
\end{array}
$$

$>\mathbf{5 0 , 0 0 0}$

$\delta^{13} C=-29.3 \%$

Compressed peat clast redeposited on present beach.

General Comment (DMM): dates on wood and peat in Wadsworth and Haeger Till are too old for stratigraphic units and samples were evidently redeposited during ice advances that deposited these tills. Peat clast evidently ripped from below present level of Lake Michigan by waves. It probably represents interstadial dated by Gephart, Managham, and Larson (1983) at ca 40,000 BP or greater.

\section{Illinois}

\section{DuPage Mammoth site series, NIU-11 23}

Lake clay and mastodon bone from DuPage Co, $1.7 \mathrm{~km} \mathrm{~S}$ of W Chicago $\left(41^{\circ} 50^{\prime} 52^{\prime \prime} \mathrm{N}, 88^{\circ} 11^{\prime} 42^{\prime \prime} \mathrm{W}\right)$. Coll 1977 and subm by J W Springer, N Illinois Univ, DeKalb, Illinois.

\section{ISGS-465. JWS-1}

$15,240 \pm 120$

Lake clay with peat from base of glacial kettle, assoc with mastodon bones. Comment (JWS): date is incompatible with previously accepted age of underlying W Chicago till and outwash of ca 14,500 BP (Frye \& Willman, 1973). We prefer younger date from same site, ISGS-485: 13,130 $\pm 350 \mathrm{BP}$ (Springer \& Flemal, 1981).

ISGS-485. JWS-2

$13,130 \pm 350$

Mastodon bone from waterlogged blue clay accumulated in bottom of glacial lake. Comment (JWS): date is compatible with previously accepted age of underlying W Chicago till and outwash of ca 14,500 BP.

\section{NIU-28 series}

Wood and mastodon bone from LaSalle Co, $5.25 \mathrm{~km} \mathrm{SW}$ of Somonauk $\left(41^{\circ} 36^{\prime} 48^{\prime \prime} \mathrm{N}, 88^{\circ} 44^{\prime} 42^{\prime \prime} \mathrm{W}\right)$. Coll 1976 by Richard Lange; subm by J W Springer.

ISGS-482. 28-C

$12,410 \pm 130$

Wood from olive-gray clay containing bones. Comment (JWS): sample comes from same depth as mastodon bones. Date suggests that accumulation of clay began as much as $1400 \mathrm{yr}$ before mastodon was buried. 
ISGS-483. 28-B

$11,080 \pm 350$

Wood from fine gravel layer. Comment (JWS): date agrees with ISGS489 (on mastodon bone). Fine gravel in which sample occurred is often found immediately surrounding mastodon bones. Sample should provide good date for bones themselves.

ISGS-489A. 28-C. Apatite fraction $10,890 \pm 210$

ISGS-489B. 28-C. Total organic fraction $10,990 \pm 110$

Mastodon bone with olive-gray clay. Comment (JWS): dates are in excellent agreement with ISGS-483 and each other.

\section{Park Page Dam series}

Wood from Winnebago Co, NW edge of Rockford $\left(42^{\circ} 18^{\prime} 30^{\prime \prime} \mathrm{N}, 89^{\circ}\right.$ $\left.10^{\prime} \mathrm{W}\right)$. From boring RD-24, at contact of water-lain silt and overlying gravel. Coll 1979 by Ron Pearson; subm by R C Anderson, Augustana Coll, Rock Island, Illinois.

ISGS-647. RCA-1

ISGS-720. RCA-1 (Repeat run)

$$
\begin{aligned}
& >39,000 \\
& \delta^{13} C=-25.7 \% \\
& >\mathbf{5 0 , 0 0 0} \\
& \delta^{13} C=-25.7 \%
\end{aligned}
$$

General Comment (RCA): sample was recovered from top of laminated silt that probably represents ponding of water in front of advancing Altonian ice. These lacustrine sediments were then covered by glacio-fluvial sand and gravel deposited as ice drew nearer. Eventually Winnebago Till was deposited at time of max ice advance. Both dates lead to similar conclusion that till is Illinoian or even older.

\section{Athens N Quarry series}

Samples from Menard Co, ca $6.5 \mathrm{~km}$ NNE of Athens $\left(40^{\circ} 00^{\prime} 50^{\prime \prime} \mathrm{N}, 89^{\circ}\right.$ $42^{\prime} 16^{\prime \prime} \mathrm{W}$ ). Coll 1980 and 1981 by L R Follmer and W H Johnson; subm by L R Follmer, ISGS.

ISGS-684. 6.35 to $6.53 \mathrm{~m}$

$41,770 \pm 1100$

$\delta^{13} \mathrm{C}=-29.0 \%$

Washed organic debris from degraded Ab soil in Berry Clay, 6.35 to $6.53 \mathrm{~m}$ below surface.

ISGS-688.

Base soluble fraction of ISGS-684.

ISGS-870. 230N-1

Organic silt from $\mathrm{Ab}$ horizon of leached soil. $\mathbf{3 5 , 5 6 0} \pm \mathbf{9 0 0}$

$\delta^{13} \mathrm{C}=-28.8 \%$

$35,750 \pm 620$

$\delta^{13} C=-28.4 \%$ 
ISGS-883. 230N-2

$37,000 \pm 1200$
$\delta^{13} C=-26.9 \%$ surface.

Organic silt from Ab zone of lower Altonian soil, 5.75 to $5.78 \mathrm{~m}$ below

General Comment (LRF): ISGS-684 dates organic debris in A horizon of Sangamon Soil developed in accretionary deposits (Berry Clay) of early Wisconsinan age. This horizon is top of upward growing soil and is abruptly separated from overlying Roxana Silt. ISGS-688 dates total humic acids extracted from ISGS-684 and indicates that amount of alluvial contamination into Sangamon through Roxana is low. These results suggest that beginning of main body of Roxana loess is ca 45,000 BP or slightly older (Follmer, 1983). ISGS-870 and -883 date A horizons of unnamed soils in alternating sequence of $\mathrm{A}$ and $\mathrm{Bg}$ horizons which overlie non-stratified Roxana Silt and underlie Farmdale Soil profile described by Follmer et al (1979). These two horizons appear to represent stratigraphic split of horizon dated 38,920 \pm 1100 BP (ISGS-654: R, 1981, v 23, p 364) exposed in previous quarry exposure.

ISGS-673. C-502 + 89, 34.5

$33,000 \pm 1000$

$\delta^{13} C=-25.0 \%$

Wood from Sangamon Co, $1 \mathrm{~km}$ E of Springfield $\left(39^{\circ} 47^{\prime} 10^{\prime \prime} \mathrm{N}, 89^{\circ} 34^{\prime}\right.$ $40^{\prime \prime} \mathrm{W}$ ), from dark gray clay in Altonian alluvium, $10.5 \mathrm{~m}$ below surface. Coll 1979 and subm by L R Follmer. Comment (LRF): date is estimate of beginning of aggradation in Sugar Creek near confluence with Sangamon R.

\section{ISGS-676. Consolidation Coal-Burning Star, H-1}

$(\mathbf{9 8 . 5} \pm \mathbf{0 . 4}) \%$ modern $\delta^{13} C=-25.3 \%$

Wood from Perry Co, $12 \mathrm{~km}$ WSW of Pinckneyville $\left(38^{\circ} 02^{\prime} 15^{\prime \prime} \mathrm{N}, 89^{\circ}\right.$ $\left.300^{\prime} 00^{\prime \prime} \mathrm{W}\right)$, from wood-rich layer in alluvium, 3.05 to $3.96 \mathrm{~m}$ below surface. Coll 1979 by Stan Harris, subm by L R Follmer and Stan Harris, Dept Geol, $\mathrm{S}$ Illinois Univ, Carbondale.

\section{ISGS Test Site DAA-19 series}

Organic silt and clay from Coles Co, $4 \mathrm{~km} \mathrm{~S}$ of Ashmore $\left(39^{\circ} 29^{\prime} 17^{\prime \prime} \mathrm{N}\right.$, $\left.88^{\circ} 01^{\prime} 20^{\prime \prime} \mathrm{W}\right)$. Coll 1980 by P C Reed and W J Morse; subm by P C Reed, ISGS.

\section{ISGS-681. $36.6 \mathrm{~m}$}

$32,620 \pm 650$

From organic zone incorporated in clay and silt, $36.6 \mathrm{~m}$ below surface.

$\delta^{13} \mathrm{C}=-28.1 \%$

$\begin{array}{lll} & & 25,170 \pm 150\end{array}$

From same organic zone as ISGS-681, 33.5m below surface.

General Comment (PCR): ISGS-686 yields Farmdalian age, whereas ISGS681 yields age which correlates favorably with Plano Silt dates in N Illinois. 
Dates suggest that reliable geochronol data can be obtained using mud rotary drill cuttings.

\section{Greenway school series}

Combined organic fragments and silt $(<10 \mu \mathrm{m}$ fraction) from Ogle Co, $3.2 \mathrm{~km} \mathrm{NW}$ of Esmond (42 $03^{\prime} 22^{\prime \prime} \mathrm{N}, 88^{\circ} 57^{\prime} 39^{\prime \prime} \mathrm{W}$ ), from lacustrine silt with small wood fragments, 7.5 to $7.7 \mathrm{~m}$ below surface. Coll 1980 by L R Follmer and R J Krumm; subm by L R Follmer.

ISGS-722. LRF-80-0-2\&3

ISGS-724. LRF-80-0-4\&5

Split of ISGS-722.

General Comment (LRF): ISGS-722 and -724 represent field replicates from four cores. Previous sampling at same site yielded age of 23,750 $\pm 950 \mathrm{BP}$ (I-2784, William \& Frye, 1970), which was suspected to be in error. Samples are from stratified zone under Esmond Till, thought to be oldest Woodfordian (late-Wisconsinan) till in Illinois. Subsequent studies showed that Sangamon Soil occurs on Esmond in locations which are rarely preserved. Esmond correlates to youngest Illinoian (Radnor) till in Central Illinois.

\section{ISGS-723. TA-3, S-7}

Organic rich silt with wood chips from Macon Co, $2.7 \mathrm{~km}$ NW of Macon $\left(39^{\circ} 44^{\prime} 01^{\prime \prime} \mathrm{N}, 89^{\circ} 01^{\prime} 02^{\prime \prime} \mathrm{W}\right)$, from top of organic zone, $20.7 \mathrm{~m}$ below surface. Coll 1980 and subm by W J Morse, ISGS. Comment (WJM): date confirms that paleosol is Robein Silt of Farmdalian age. Location at margin of Shelbyville moraine helps date max Wisconsinan ice advance.

\section{ISGS-727. TA-6, S-9}

Brown to reddish brown organic silt from Macon Co, $1.2 \mathrm{~km} \mathrm{NE}$ of Elwin ( $\left.39^{\circ} 47^{\prime} 10^{\prime \prime} \mathrm{N}, 88^{\circ} 58^{\prime} 59^{\prime \prime} \mathrm{W}\right)$, from upper part of organic silt, 26.8 to $27.8 \mathrm{~m}$ below surface. Coll 1980 and subm by WJ Morse. Comment (WJM): helps date max Wisconsinan ice advance and agrees with other dates near margin of Shelbyville moraine.

\section{Pittsburg Basin series}

Peaty gyttja from Fayette Co, $10 \mathrm{~km} \mathrm{SW}$ of Vandalia $\left(38^{\circ} 54^{\prime} 15^{\prime \prime} \mathrm{N}, 89^{\circ}\right.$ $11^{\prime} 10^{\prime \prime}$ W). Coll 1979 by H E Wright, L R Follmer and John King; subm by John King, Univ Minnesota.

\section{ISGS-738. PBS-79D \# 1}

$32,590 \pm 930$

From lake sediment core, 263 to $265 \mathrm{~cm}$ interval. $\delta^{13} C=-24.8 \%$ 
ISGS-748. PBS-79D \#2

$39,800 \pm 1200$

From lake sediment core, 269 to $271 \mathrm{~cm}$ interval.

ISGS-746. PBS-79D \#3

$\delta^{13} C=-25.5 \%$

From lake sediment core, 275 to $277 \mathrm{~cm}$ interval.

ISGS-750. PBS-79D \#4

$$
\begin{aligned}
& >42,000 \\
\delta^{13} C= & -27.4 \% \text { o }
\end{aligned}
$$

From lake sediment core, 281 to $283 \mathrm{~cm}$ interval.

$$
\begin{array}{r}
\mathbf{4 0 , 0 3 0} \pm \mathbf{9 9 0} \\
\delta^{13} C=-26.8 \% 0
\end{array}
$$

\section{ISGS-742. PBS-79D \#5}

$41,110 \pm 810$

From lake sediment core, 289 to $291 \mathrm{~cm}$ interval.

$$
\delta^{13} C=-28.3 \%
$$

\section{Oak Crest Subdivision series}

Muck and peat from Winnebago Co, $8 \mathrm{~km} \mathrm{SW}$ of Calendonia $\left(42^{\circ} 20^{\prime}\right.$ $02^{\prime \prime} \mathrm{N}, 88^{\circ} 59^{\prime} 11^{\prime \prime} \mathrm{W}$ ). Coll 1980 and 1982 by R C Berg and L R Follmer; subm by R C Berg, ISGS.

\section{ISGS-749. Site 1, RCB-WB-6}

$33,220 \pm 710$

$\delta^{13} \mathrm{C}=-28.4 \%$

From organic silt zone, 1.98 to $2.29 \mathrm{~m}$ interval in open-bucket auger.

ISGS-744. Site 1, RCB-WB-18 \& 19

$\mathbf{4 7 , 4 0 0} \pm \mathbf{2 4 0 0}$

From 2.89 to $3.05 \mathrm{~m}$ interval in muck zone.

$$
\delta^{13} C=-28.1 \%
$$

ISGS-1039. Site 2, RCB-1

$\mathbf{2 4 , 8 3 0} \pm \mathbf{3 5 0}$

$\delta^{13} C=-29.6 \%$

From 1.02 to $1.14 \mathrm{~m}$ interval in sand interbedded clay zone.

ISGS-1073. Site 2, RCB-2

$37,900 \pm 1300$

From peat zone, 1.55 to $1.63 \mathrm{~m}$ interval.

$$
\delta^{13} C=-28.0 \% 0
$$

ISGS-1069. Site 2, RCB-3

$43,800 \pm 2700$

From fibrous peat zone, 1.85 to $1.98 \mathrm{~m}$ interval.

ISGS-1045. Site 2, RCB-4

$43,100 \pm 1100$

$\delta^{13} C=-29.1 \%$

From very fibrous peat zone, 2.54 to $2.64 \mathrm{~m}$ interval.

General Comment (RCB): ISGS-749 agrees well with date of upper limit of Plano Silt member of the Winnebago Fm, GrN-4408: 32,600 \pm 520 (Willman \& Frye, 1970). ISGS-744 provides lower limit of Plano Silt member. 
ISGS-1039, -1073, -1069, and -1045 cstablish higher limit for bog sequence. These four dates document pine to spruce transition shown in pollen analysis and establish upper time limit for underlying Argyle Till member.

\section{ISGS-757. Camp Sagawau}

$1940 \pm 80$

$\delta^{13} C=-25.4 \%$

Decomposed woody materials from Cook Co, $5 \mathrm{~km} \mathrm{E}$ of Lemont $\left(41^{\circ}\right.$ $41^{\prime} 14^{\prime \prime} \mathrm{N}, 87^{\circ} 52^{\prime} 45^{\prime \prime} \mathrm{W}$ ), from sandy and silty fluvial or lacustrine deposit, ca $3 \mathrm{~m}$ below surface. Coll 1980 by W G Dixon and Ralph Trornton; subm by W G Dixon, ISGS. Comment (WGI)): exposures in stream bed were considered to be Lemont Drift, and strata in which decomposed wood was contained were of younger but indeterminate age. This sample is probably root from Late Holocene tree. In situ woody material appears to be decomposed $\log$ which had been compressed by weight of overlying sediments.

\section{ISGS-765. Mahomet NE Bridge}

Wood from Champaign Co, $0.8 \mathrm{~km}$ E of Mahomet $\left(40^{\circ} 11^{\prime} 04^{\prime \prime} \mathrm{N}, 88^{\circ}\right.$ $23^{\prime} 28^{\prime \prime} \mathrm{W}$ ), from $1.5 \mathrm{~m}$ below top of Piatt till. Coll 1980 by L R Follmer, W H Johnson, and W J Morse; subm by W J Morse. Comment (WJM): Piatt till is already known to be younger than Farmdalian. Date of $>38,000$ does not further define age of unit.

\section{ISGS-767. Sunnycrest Drainage Ditch}

$17,690 \pm 270$

Twigs and root fragments from Champaign $\mathrm{Co}, 3.6 \mathrm{~km} \mathrm{SE}$ from downtown Urbana $\left(40^{\circ} 05^{\prime} 50^{\prime \prime} \mathrm{N}, 88^{\circ} 10^{\prime} 10^{\prime \prime} \mathrm{W}\right)$, from 2.05 to $2.15 \mathrm{~m}$ below top of Richland Loess. Coll 1980 and subm by W H Johnson. Comment (WHJ): date is min for deglaciation from Urbana Moraine and for Batestown Till member of Wedron Fm. This is oldest date from sediment overlying Wedron Fm in Illinois.

\section{ISGS-772. Nimitz Quarry Section}

$47,400 \pm 1500$

$\delta^{13} C=-25.9 \%$

Wood from Winnebago Co, $4 \mathrm{~km}$ ENE of Loves Park $\left(42^{\circ} 19^{\prime} 48^{\prime \prime} \mathrm{N}\right.$, $89^{\circ} 00^{\prime} 07^{\prime \prime} \mathrm{W}$ ), from organic zone, 8.5 to $9.5 \mathrm{~m}$ below surface. Coll 1980 by R C Berg, L. R Follmer, and J P Kempton; subm by R C Berg. Comment (RCB): date is younger than stratigraphic evidence and nearby ${ }^{14} \mathrm{C}$ dates had suggested.

\section{ISGS-778. B W project}

$$
\delta^{13} C=\begin{array}{r}
>\mathbf{4 8 , 0 0 0} \\
-30.3 \%
\end{array}
$$

Organic silt with wood fragments from Winnebago Co, $3 \mathrm{~km} \mathrm{WNW}$ of Rockton $\left(42^{\circ} 27^{\prime} 38^{\prime \prime} \mathrm{N}, 89^{\circ}() 6^{\prime} 22^{\prime \prime} \mathrm{W}\right)$, from dark gray leached organic silt zone, 45.9 to $46.1 \mathrm{~m}$ below surface. Coll 1980 and subm by R C Berg. Comment (RCB): date verifies suspected Early Altonian or pre-Wisconsinan age for bulk of Rock Bedrock valley fill. 
ISGS-828. Clinton power station, \#1

Moss from DeWitt Co, $8 \mathrm{~km} \mathrm{E}$ of Clinton $\left(40^{\circ} 10^{\prime} 09^{\prime \prime} \mathrm{N}, 88^{\circ} 50^{\prime} 20^{\prime \prime} \mathrm{W}\right)$, from moss bed, 1 to $2 \mathrm{~cm}$ thick, $10 \mathrm{~cm}$ below Wedron till in Morton loess. Coll 1981 and subm by J E King.

\section{ISGS-829. Mussel Beach, MB-50}

$$
\begin{array}{r}
\mathbf{5 6 8 0} \pm \mathbf{8 0} \\
\delta^{13} C=-8.8 \% \text { o }
\end{array}
$$

Mussel shells from Rock Island Co, $7 \mathrm{~km} \mathrm{SW}$ of Rock Island $\left(41^{\circ} 28^{\prime}\right.$ $04^{\prime \prime} \mathrm{N}, 90^{\circ} 38^{\prime} 27^{\prime \prime} \mathrm{W}$ ), from top of buried sandy loam beach ridge assoc with Indian artifacts. Coll 1981 by M L Barnhardt and P F Person; subm by M L Barnhardt, Illinois State Univ, Normal, Illinois. Comment (MLB): these mussel shells are found at contact between underlying beach sand and sediments deposited during various slough and backwater periods. With ISGS842 , it helps establish rate of deposition in area.

\section{ISGS-842. Beach Ridge}

$$
\begin{array}{r}
\mathbf{3 6 7 0} \pm \mathbf{8 0} \\
\delta^{13} C=-25.0^{\circ} \% 0
\end{array}
$$

Organic rich soil from Rock Island $\mathrm{Co}, 8 \mathrm{~km} \mathrm{SW}$ of Rock Island $\left(41^{\circ} 27^{\prime}\right.$ $40^{\prime \prime} \mathrm{N}, 90^{\circ} 38^{\prime} 45^{\prime \prime} \mathrm{W}$ ), from base of abandoned beach ridge, $1.5 \mathrm{~m}$ below surface. Coll 1981 by M L Barnhardt and P F Peason; subm by M L Barnhardt. Comment (MLB): date agrees with ISGS-829, from beach ridge farther from river in same area.

\section{Wedron Section series}

Wood from LaSalle Co, $0.6 \mathrm{~km} \mathrm{~S}$ of Wedron $\left(41^{\circ} 25^{\prime} 52^{\prime \prime} \mathrm{N}, 88^{\circ} 46^{\prime} 50^{\prime \prime}\right.$ W). Coll 1981 by L R Follmer and W H Johnson; subm by L R Follmer.

\section{ISGS-862. $\quad W_{9}-\mathbf{E}-1$}

From sandy alluvium, 3 to $3.5 \mathrm{~m}$ below surface.

\section{ISGS-863. $\quad W_{9}-D-1$}

From pink brown lacustrine clay, ca $10 \mathrm{~m}$ below surface.

General Comment (LRF): ISGS-862 is from top of valley fill sequence underlying stratified pinkish clay (Peddicord Fm) which cuts into St Peter Sandstone. ISGS-863 is from base of Peddicord Fm overlying normal Farmdale Soil $(\mathrm{A} / \mathrm{Bg} / \mathrm{c})$. Dates agree well with previous dates on wood from Peddicord at this site and with date from top of Farmdale Soil in other places. Peddicord Fm is now interpreted to represent slack water lake formed at end of Farmdalian during onset of Woodfordian (late Wisconsinan) glaciation.

\section{McKee Farm series}

Carbonaceous silt from McDonough Co, $6 \mathrm{~km} \mathrm{~N}$ of Macomb $\left(40^{\circ} 30^{\prime}\right.$ $43^{\prime \prime} \mathrm{N}, 90^{\circ} 40^{\prime} 27^{\prime \prime} \mathrm{W}$ ). Coll 1979 by J E King and W H Johnson; subm by W H Johnson, Dept Geol, Univ Illinois. 
ISGS-1041. MF-1

$25,260 \pm 280$

From Robein Silt at depth 2.63 to $2.68 \mathrm{~m}$. Comment (WHJ): date is from near top of carbonaceous sequence of deposits; it marks approx position where large increase in spruce occurs in sediment.

\section{ISGS-1042. MF-B}

$37,800 \pm 2100$

$\delta^{13} \mathrm{C}=-29.0 \%$

From Robein/Roxana at depth 3.13 to $3.2 \mathrm{~m}$. Comment (WHJ): date is from middle to lower part of carbonaceous sequence of deposits and is $0.4 \mathrm{~m}$ above position of ISGS-975. Both dates are the same. Origin of discrepancy is not clear.

ISGS-975. MF-A

$\mathbf{3 7 , 7 0 0} \pm \mathbf{1 4 0 0}$

$\delta^{13} \mathrm{C}=-29.0 \%$

From Robein Silt at depth 3.55 to $3.65 \mathrm{~m}$. Comment (WHJ): date is from base of carbonaceous sequence of deposits; it marks approx position where spruce pollen begins to occur in sediment.

\section{Sangamon Sewer Site series}

Wood from Champaign Co, $3.1 \mathrm{~km}$ NE of Mahomet $\left(40^{\circ} 12^{\prime} 58^{\prime \prime} \mathrm{N}, 88^{\circ}\right.$ 22' 42" W). Coll 1982 by W H Johnson and D I Casavant; subm by W H Johnson.

\section{ISGS-1074. \#15}

$\mathbf{1 1 , 5 5 0} \pm \mathbf{1 3 0}$

From sandy sitt ca $3.6 \mathrm{~m}$ below ground surface. Comen on wood $0.5 \mathrm{~m}$ above base of post occurs above erosion surface cut on glaciofluvial deposits of Henry Fm.

\section{ISGS-1077. \#10}

$5080 \pm 70$

$$
\delta^{13} C=-27.0 \%
$$

From base of $2.5 \mathrm{~m}$ sequence of overbank sediments in Cahokia Alluvium. Comment $(\mathrm{WJH})$ : date marks beginning of overbank sedimentation in abandoned channel cut in older Holocene alluvium.

\section{Becker-Schumann Farm series}

Wood charcoal from Calhoun Co, $5 \mathrm{~km} \mathrm{NW}$ of Kampsville (39 $19^{\prime} 56^{\prime \prime}$ N, $90^{\circ} 39^{\prime} 49^{\prime \prime}$ W). Coll 1978 and subm by R T Styles.

ISGS-867. TRS-1

$$
\begin{array}{r}
1010 \pm 100 \\
\delta^{13} C=-26.2^{0} \%
\end{array}
$$

From near boundary of two main units of Holocene creek alluvium in lens of light gray silt.

\section{ISGS-871. TRS-2}

From silty creek alluvium, ca $90 \mathrm{~cm}$ below surface in creek bank. 
General Comment (RTS): dates suggest extensive Late Holocene fluvial activity in small upland drainage in W Illinois. ISGS-867 reflects waning stage of Butzer's (1977) proposed upland erosion phase, which ranges from ca 1200 to 950 BP ISGS-871 indicates that fluvial activity continued into more recent time, at least on local level.

\section{Hartwell Levee District series}

Samples from Greene Co, 2.7 to $7.7 \mathrm{~km} \mathrm{SW}$ of Hillview $\left(39^{\circ} 23^{\prime} 26^{\prime \prime} \mathrm{N}\right.$, $90^{\circ} 33^{\prime}$ to $34^{\prime}$ W). Coll 1981 by E R Hajic and D S Leigh; subm by E R Hajic, Geomorphol Lab, Northwestern Univ, Evanston, Illinois.

\section{ISGS-900. HLC-38C, D}

$13,010 \pm 140$

$\delta^{13} C=-26.3 \%$

Wood conifer from dark, unleached, laminated slackwater silt and clayey silt below N-most remnant of Deer Plain terrace clays. Comment (ERH): date is max for Deer Plain terrace and assoc lacustrine clay in lower Illinois R valley. Date agrees with ISGS-894 (13,390 190 BP, Hajic, 1983) and ISGS-875 (13,360 $\pm 100 \mathrm{BP}$, Wiant, Hajic \& Styles, 1983) from same or related lithologic unit, same stratigraphic position, and similar botanical components.

\section{ISGS-903. HLC-42 A\&B}

$$
\begin{array}{r}
\mathbf{3 6 5 0} \pm \mathbf{7 0} \\
\delta^{13} C=-27.5 \% 0
\end{array}
$$

Wood and charcoal from base of dark gray, unleached clayey silt. Comment (ERH): date is max for end of paleochannel infilling episode (Hajic, 1983).

ISGS-930. HLC-11 A\&B

$$
\begin{array}{r}
5700 \pm 140 \\
\delta^{13} C=-26.0 \%
\end{array}
$$

From base of thick sequence of channel-filling dark gray, unleached, clayey silts and top portion of underlying black unleached fine to medium sand. Comment (ERH): date is min for start of paleochannel infilling primarily with slackwater deposits. Lithologic unit from which this sample was coll constitutes bulk Holocene Valley fill (Hajic, 1983).

\section{Nutwood Levee District series}

Uncarbonized wood (spruce and cedar) from Jersey Co, 3.9 to $5.5 \mathrm{~km} \mathrm{E}$ of Hardin $\left(39^{\circ} 09^{\prime} \mathrm{N}, 90^{\circ} 33^{\prime}\right.$ to $\left.34^{\prime} \mathrm{W}\right)$. Coll 1981 and subm by E R Hajic.

\section{ISGS-894. 12.84 to $13.20 \mathrm{~m}$}

$$
13,390 \pm 190
$$

From dark gray, unleached, laminated slackwater silt and sand silt beneath Deer Plain terrace and assoc lacustrine clays and alluvial fan silts along E margin of Illinois R Valley. Comment (ERH): date is min for initiation of Valley-wide lacustrine environment in lower Illinois R Valley (Hajic, 1983). 
ISGS-911. 3.65 to $4.80 \mathrm{~m}$

$12,000 \pm 100$

From slightly sandier zone near upper part of unoxidized, unleached, laminated slackwater silt and clay unit believed to be within eroded remnant of Keach Scholl terrace. Comment (ERH): max age for Keach Scholl terrace and min age for Deer Plain terrace in lower Illinois R Valley (Hajic, 1983).

\section{Indiana}

ISGS-424. Harrodsburg Crevice

$25,050 \pm 660$

Apatite fraction of bone from Monroe Co, $14 \mathrm{~km} \mathrm{~S}$ of Bloomington $\left(39^{\circ} 02^{\prime} 30^{\prime \prime} \mathrm{N}, 86^{\circ} 32^{\prime} 30^{\prime \prime} \mathrm{W}\right)$, from crevice-type cave deposit. Coll 1974 by P J Munson; subm by P W Parmalee, Univ Tennessee. Comment (PWP): preliminary analyses of faunal materials from Harrodsburg Crevice suggest locale served as both habitation and denning site.

\section{Adams Mill series}

Samples from Carroll Co, $2 \mathrm{~km}$ NE of Cutler $\left(40^{\circ} 29^{\prime} 02^{\prime \prime} \mathrm{N}, 86^{\circ} 30^{\prime} 12^{\prime \prime}\right.$ W). Coll 1979 and 1981 and subm by N K Bleuer, Indiana Geol Survey.

ISGS-677. NKB-79-1

$22,950 \pm 160$

Wood from till assoc with deforr below surface.

\section{ISGS-952. NKB-81-2}

$22,350 \pm 120$

Wood chips from organic silt zone, ca $30 \mathrm{~cm}$ thick.

\section{ISGS-977. NKB-81-1}

Muck from atop Adams Mill Beds.

General Comment (NKB): all three dates seem somewhat older than expected for this location.

\section{3-15-6 series}

Organic silt from Parke Co, 5.5km SE of Bellmore $\left(39^{\circ} 00^{\prime} 44^{\prime \prime} \mathrm{N}, 87^{\circ}\right.$ $\left.00^{\prime} 41^{\prime \prime} \mathrm{W}\right)$, from silt assoc with fibrous organic debris. Coll 1979 and subm by $\mathrm{N}$ K Bleuer.

\section{ISGS-679. 4.26 to $4.41 \mathrm{~m}$}

ISGS-707. 3.96 to $4.11 \mathrm{~m}$

$$
\begin{array}{r}
\mathbf{2 4 , 2 4 0} \pm \mathbf{2 7 0} \\
\delta^{13} C=-18.7 \% 0 \\
\mathbf{2 3 , 5 4 0} \pm \mathbf{5 4 0} \\
\delta^{13} C=-28.9 \% 0
\end{array}
$$

General Comment (NKB): dates are assumed to antedate ice advance by considerable length of time. 
ISGS-682. 13-15-17

$\mathbf{2 3 , 4 8 0} \pm \mathbf{1 0 0}$

$\delta^{13} \mathrm{C}=-26.6 \%$

Organic silt from Parke Co, $7 \mathrm{~km}$ ESE of Rockville $\left(39^{\circ} 45^{\prime} 10^{\prime \prime} \mathrm{N}, 87^{\circ}\right.$ $08^{\prime} 04^{\prime \prime} \mathrm{W}$ ), from silty muck and organic silt, grading to clayey black mineral soil at base, 4.41 to $5.18 \mathrm{~m}$ below surface. Coll 1979 and subm by $\mathrm{N} \mathrm{K}$ Bleuer. Comment (NKB): date is assumed to antedate actual ice advance.

\section{ISGS-690. Green Castle Quarry}

$20,080 \pm 100$

Woody debris from Putnam Co, $1.5 \mathrm{~km}$ W of Green Castle $\left(39^{\circ} 37^{\prime} 47^{\prime \prime}\right.$ $\mathrm{N}, 86^{\circ} 53^{\prime} 00^{\prime \prime} \mathrm{W}$ ), from top mat layer of silt zone. Coll 1979 and subm by $\mathrm{N}$ K Bleuer. Comment (NKB): date indicates that overlying till is not direct correlation (in time or event) of Wayne's Center Grove Till of Johnson Co.

\section{ISGS-717. Ambia Teays Test \#1}

$\mathbf{2 5 , 4 5 0} \pm \mathbf{4 8 0}$

Organic silt from Benton Co, $1.5 \mathrm{~km}$ E of Ambia $\left(40^{\circ} 29^{\prime} 12^{\prime \prime} \mathrm{N}, 87^{\circ} 29^{\prime}\right.$ $27^{\prime \prime} \mathrm{W}$ ), from silt to silty clay zone, slightly organic stained in top part, 23.8 to $27.4 \mathrm{~m}$ below surface. Coll 1979 and subm by N K Bleuer. Comment (NKB): assumed to date Wisconsinan Fairgrange advance at that place. It is not out of line with dates in Illinois at that lat, but is much older than basal Trafalgar dates in central and NE Indiana.

\section{ISGS-880. Liverpool Section}

$$
\begin{array}{r}
11,290 \pm 80 \\
\delta^{13} C=-26.9 \% \text { o }
\end{array}
$$

Wood fragments from peat from Lake Co, $1 \mathrm{~km}$ E of Liverpool $\left(41^{\circ} 32^{\prime}\right.$ $50^{\prime \prime} \mathrm{N}, 87^{\circ} 16^{\prime} 26^{\prime \prime} \mathrm{W}$ ), from peat bed in cross-bedded and laminated sand. Coll 1981 by Perry Zack and A T Smith; subm by R B Votaw, Indiana Univ NW, Gary, Indiana. Comment (RBV): site is in Calumet stage shoreline sands and provides date for near Two-Creekan age materials in Indiana.

\section{ISGS-941. Alcoa production well}

$$
\delta^{13} C=\begin{array}{r}
>\mathbf{3 1 , 0 0 0} \\
-26.4 \% 0
\end{array}
$$

Organic silt from Tippecanoe Co, SE edge of Lafayette $\left(40^{\circ} 24^{\prime} 03^{\prime \prime} \mathrm{N}\right.$, $86^{\circ} 51^{\prime} 59^{\prime \prime} \mathrm{W}$ ), from soft blue clay layer, $36.27 \mathrm{~m}$ below surface. Coll 1981 by Peerless-Midwest Co Drillers; subm by N K Bleuer. Comment (NKB): date suggests that some or all of primary gravel package in S Lafayette may be pre-Wisconsinan.

\section{ISGS-942. Kokomo USGS-D-7}

$41,600 \pm 2200$

$\delta^{13} \mathrm{C}=-29.5 \%$

Organic silt from Howard Co, $4.5 \mathrm{~km} \mathrm{NW}$ of Kokomo $\left(40^{\circ} 33^{\prime} 05^{\prime \prime} \mathrm{N}\right.$, $\left.86^{\circ} 14^{\prime} 34^{\prime \prime} \mathrm{W}\right)$, from 16.76 to $17.37 \mathrm{~m}$ in auger hole D-7B. Coll 1981 by B Compahni and R Autio; subm by N K Bleuer. Comment (NKB): date establishes sequence of three overlying tills as Wisconsinan in age, and suggests indirectly that lower till can be correlated (lithologically) to lowest till at Adams Mill locality, which overlies 20,000 BP material. Dated unit is 
assumed to be truncated and to indicate long record of mid-Wisconsin accumulation.

\section{Pyle Site series}

Samples from Adams Co, 6km ENE of Berne $\left(40^{\circ} 40^{\prime} 32^{\prime \prime} \mathrm{N}, 84^{\circ} 53^{\prime}\right.$ $19^{\prime \prime} \mathrm{W}$ ), from sediment core. Coll 1980 by L C Shane and H E Wright; subm by L C Shane, Limnol Research Center, Univ Minnesota.

\section{ISGS-1052. 190 to $193 \mathrm{~cm}$ depth}

Only wood sample from this series; others are gyttya.

ISGS-1066. 257.5 to $260 \mathrm{~cm}$

ISGS-1076. 313 to $315 \mathrm{~cm}$

ISGS-1068. 350 to $355 \mathrm{~cm}$

\section{ISGS-1055. 440 to $445 \mathrm{~cm}$}

$\mathbf{9 2 4 0} \pm \mathbf{8 0}$
$\delta^{13} C=-26.2 \% 0$

$10,170 \pm 70$

$\delta^{13} C=-31.9 \%$

$9080 \pm 180$

$\delta^{13} \mathrm{C}=-31.0 \%$

$11,930 \pm 90$

$\delta^{13} C=-26.4 \%$

$13,510 \pm 160$

$\delta^{13} C=-29.2 \%$

General Comment (LCS): five dates from Pyle site, NE Indiana, date major changes in late-glacial pollen record of region. Series was designed to confirm chronology of other nearby sites and to focus specifically on recurrence of spruce pollen dating to ca 11,000 BP. Four of five dates agree very well with other research. ISGS-1076 is out of sequence by ca $2000 \mathrm{yr}$.

\section{ISGS-1054. American Aggregates}

$\delta^{13} \mathrm{C}=-\mathbf{5 0 , 0 0 0}$

Wood from Wayne Co, $27 \mathrm{~km}$ ENE of Richmond ( $39^{\circ} 50^{\prime} 30^{\prime \prime} \mathrm{N}, 84^{\circ} 49^{\prime}$ $23^{\prime \prime} \mathrm{W}$ ), from organic silt bed, 15 to $30 \mathrm{~cm}$ thick, exposed on NW side of cut along abandoned railroad right-of-way. Coll 1982 and subm by B B Miller, Dept Geol, Kent State Univ, Kent, Ohio. Comment (BBM): date for this wood from unit 6 of American Aggregates pit agrees with earlier attempts to date this organic silt bed (Gooding, 1975) and suggests that mollusks from unit 6 are probably older than those recovered from unit 1 at Bantas Fork, dated by ISGS-726: 44,800 \pm 1700 (Goldthwait et al, 1981).

\footnotetext{
ISGS-1067. Wildcat Creek $21,660 \pm 240$

Wood fro Tippecan $\left.25^{\prime} 56^{\prime \prime} \mathrm{N}, 86^{\circ} 49^{\prime} 20^{\prime \prime} \mathrm{W}\right)$, from $3 \mathrm{~km} \mathrm{E}$ of Hwy 52 bypass, Lafayette $\left(40^{\circ}\right.$ Bleuer and R Pavey; subm by N K Bleuer. Comment (NKB): date corroborates units above as Wisconsinan; gives younger advance date for area than Adams Mill series.
} 
ISGS-1070. Green Creek Section A

Wood from Parke Co, $12.8 \mathrm{~km} \mathrm{~N}$ of Rockville $\left(39^{\circ} 54^{\prime} 55^{\prime \prime} \mathrm{N}, 87^{\circ} 14^{\prime}\right.$ $20^{\prime \prime} \mathrm{W}$ ), from base of till. Coll 1982 and subm by $\mathrm{N}$ K Bleuer. Comment (NKB): date indicates that till unit above is Illinoian or older.

\section{Russellville Quarry series}

Samples from Putnam Co, $0.8 \mathrm{~km}$ SSW of Russellville $\left(39^{\circ} 50^{\prime} 44^{\prime \prime} \mathrm{N}\right.$, $86^{\circ} 59^{\prime} 14^{\prime \prime} \mathrm{W}$ ). Coll 1982 and subm by N K Bleuer.

\section{ISGS-1071. 82/R-lower}

Wood from lower portion of organic silt.

\section{ISGS-1075. 82/R-upper}

Silt from top of transported organic zone. $\mathbf{2 2 , 3 6 0} \pm \mathbf{5 8 0}$

$\delta^{13} C=-25.5 \%$

$22,400 \pm 210$

$\delta^{13} C=-25.1 \%$

General Comment (NKB): ISGS-1071 is slightly older than would have been assumed. ISGS-1075 suggests that upper organic zones may be repeated as part of long basal thrust sheets.

\section{ISGS-1072. Lower Durkeys Run}

$3970 \pm 100$

$\delta^{13} C-28.9 \%$

Wood from Tippecanoe Co, in SW of Lafayette $\left(40^{\circ} 24^{\prime} 08^{\prime \prime} \mathrm{N}, 86^{\circ} 54^{\prime}\right.$ $15^{\prime \prime} \mathrm{W}$ ), from muck, marl channel fill. Coll 1982 by N K Bleuer and R Pavey; subm by $\mathrm{N}$ K Bleuer. Comment $(\mathrm{NKB})$ : date is obviously post-Wisconsinan and shows sediments to be inset alluvial fill.

\section{Ohio}

\section{ISGS-726. Bantas Fork \# 1}

$$
\begin{array}{r}
44,800 \pm 1700 \\
\delta^{13} C=-28.0 \%
\end{array}
$$

Organic silt from Preble Co, $4.8 \mathrm{~km}$ E of Eaton $\left(39^{\circ} 45^{\prime} 12^{\prime \prime} \mathrm{N}, 84^{\circ} 35^{\prime}\right.$ $05^{\prime \prime} \mathrm{W}$ ), from interstadial deposit immediately below till in which sidney weathering profile developed. Coll 1980 and subm by D P Stewart, Dept Geol, Miami Univ, Ohio. Comment (DPS): date confirms correlation of unit with New Paris Interstade and supports middle Wisconsinan age for Fairhaven till above it.

\section{ISGS-761. Doty's Highbank}

$$
\begin{array}{r}
\mathbf{2 0 , 2 1 0} \pm \mathbf{2 6 0} \\
\delta^{13} C-25.8 \% 0
\end{array}
$$

Wood (red spruce) from Butler Co, $4 \mathrm{~km} \mathrm{~N}$ of Oxford $\left(39^{\circ} 33^{\prime} 05^{\prime \prime} \mathrm{N}\right.$, $84^{\circ} 43^{\prime} 56^{\prime \prime} \mathrm{W}$ ), from stump zone, overlain and underlain by till unit. Coll 1980 and subm by D P Stewart. Comment (DPS): date corrects age of stump zone at Doty's Highbank. It also confirms correlation of Fayette till below and Shelbyville till above. 


\section{ISGS-764. Gregory Creek \#5}

$19,350 \pm 130$

Wood (red spruce) from Butler Co, $3.5 \mathrm{~km}$ SE of Lesourdsville $\left(39^{\circ} 24^{\prime \prime}\right.$ $30^{\prime \prime} \mathrm{N}, 84^{\circ} 25^{\prime} 20^{\prime \prime} \mathrm{W}$ ), from glacial till, $145 \mathrm{~cm}$ from base of till unit and interstadial deposit below. Coll 1979 by K M Newdale; subm by D P Stewart. Comment (KMN): date confirms correlation of till with upper Shelbyville till of region and suggests that this till is younger than lower Shelbyville exposed to $\mathrm{W}$.

\section{ISGS-922. E Branch Chagrin R Gravel Pit}

$$
9360 \pm 100
$$

Wood from Geauga Co, $0.75 \mathrm{~km} \mathrm{~S}$ of Lake Geauga $\left(41^{\circ} 33^{\prime} 45^{\prime \prime} \mathrm{N}, 81^{\circ}\right.$ $18^{\prime} 30^{\prime \prime} \mathrm{W}$ ), from lens of slit surrounded by gravel and exposed in face of gravel pit, $2.5 \mathrm{~m}$ below terrace surface. Coll 1981 and subm by $\mathrm{S} M$ Totten, Hanover Coll, Hanover, Indiana. Comment (SMT): date is ca $4000 \mathrm{yr}$ younger than expected. Either E Branch Chagrin R terrace is younger than believed, or leaching has resulted in sample contamination. Passage of spruce cones in deposit suggests wood is older than data indicates.

\section{Brown's Run series}

Wood from Butler Co, 6.65km SW of Germantown $\left(39^{\circ} 34^{\prime} 30^{\prime \prime} \mathrm{N}, 84^{\circ}\right.$ $26^{\prime} 00^{\prime \prime}$ W). Coll 1982 by D P Stewart and B B Miller; subm by B B Miller.

\section{ISGS-1053. 82-9b}

$20,590 \pm 190$

From organic silt lens ca $22.6 \mathrm{~m}$ below top of cut bank on $\mathrm{S} s \mathrm{de}$ Brown's Run.

\section{ISGS-1057. 82-9c}

$\mathbf{2 0 , 4 8 0} \pm 340$

From organic silt layer, ca $30 \mathrm{~cm}$ thick, ca $3.5 \mathrm{~cm}$ above silt lens in underlying sand and gravel (ISGS-1053).

General Comment (BBM): dates agree with one another and appear to support field interpretation which suggested that organic lens from which ISGS-1053 was taken may have been squeezed into enclosing sand and gravel unit. ISGS-1053 agrees well with ISGS-761: 20,210 $\pm 260 \mathrm{BP}$, from stump zone at Doty's Highbank (Goldthwait et al, 1981).

\section{New Mexico}

\section{ISGS-762. Pintado Section, NM-192}

$$
240 \pm 80
$$

$$
\delta^{13} \mathrm{C}=-22.0 \%
$$

Charcoal from Guadelupe Co, $8 \mathrm{~km} \mathrm{SW}$ of Santa Rosa $\left(34^{\circ} 25^{\prime} 36^{\prime \prime} \mathrm{N}\right.$, $\left.104^{\circ} 44^{\prime} 00^{\prime \prime} \mathrm{W}\right)$, from extensive hearth at interface between fine sand and silt units. Coll 1980 by A B Leonard and J C Frye; subm by A B Leonard and H D Glass, ISGS. 
ISGS-770. Black R Crossing, NM-134

Mollusk shell from Eddy Co, $24 \mathrm{~km} \mathrm{~S}$ of Carlsbad $\left(32^{\circ} 12^{\prime} 42^{\prime \prime} \mathrm{N}, 104^{\circ}\right.$ $13^{\prime} 18^{\prime \prime} \mathrm{W}$ ), from terrace deposit, $6 \mathrm{~m}$ thick. Coll 1977 by A B Leonard and J C Frye; subm by A B Leonard.

\section{ISGS-932. McMillan Dam S, NMF-203}

$$
\begin{array}{r}
11,150 \pm 130 \\
\delta^{13} C=-5.6 \%
\end{array}
$$

Shell fragments of Unionid mussels from Eddy Co, $0.1 \mathrm{~km} \mathrm{~S}$ of Lake McMillan Reservoir ( $32^{\circ} 38^{\prime} 11^{\prime \prime} \mathrm{N}, 104^{\circ} 20^{\prime} 42^{\prime \prime} \mathrm{W}$ ), from river terrace W of Pecos R channel, ca $4 \mathrm{~m}$ above channel sediments. Coll 1981 by J C Frye and A B L.conard; subm by A B L ceonard and H D Glass.

\section{ISGS-998. Hagerman N Section, NMF-202A}

$$
\begin{array}{r}
950 \pm 100 \\
\delta^{13} C=-23.7 \% 0
\end{array}
$$

Organic debris from Chaves Co, 4.8km NNE of Hagerman $\left(33^{\circ} 08^{\prime} 24^{\prime \prime}\right.$ $\mathrm{N}, 104^{\circ} 19^{\prime} 48^{\prime \prime} \mathrm{W}$ ), from terrace sediments on Rio Felix. Coll 1981 by J C Frye and A B Leonard; subm by A B Leonard.

\section{ISGS-1002. Trujillo Ranch Section}

$$
\begin{array}{r}
15,730 \pm 240 \\
\delta^{13} C=-7.8 \%
\end{array}
$$

Gastropod shells from DeBaca Co, $9.7 \mathrm{~km}$ SSW dam at Lake Sunner $\left(34^{\circ} 32^{\prime} 31^{\prime \prime} \mathrm{N}, 104^{\circ} 25^{\prime} 26^{\prime \prime} \mathrm{W}\right)$, from dry lake sediments exposed by erosion. Coll 1981 by J C Frye and A B Leonard; subm by A B Leonard.

\section{California}

\section{Proposed Little Cojo Bay LNG Site series}

Marine shells from Santa Barbara Co (34 $27^{\prime} 03^{\prime \prime} \mathrm{N}, 120^{\circ} 25^{\prime} 08^{\prime \prime} \mathrm{W}$ ), from marine sands overlying marine abrasion platform of first emergent marine terrace exposed in seacliff. Coll 1980 by R H Patterson; subm by D L Johnson, Univ Illinois.

ISGS-714. COJO-2

\section{ISGS-716. COJO-1}

\section{ISGS-718. Beach Fault Trench terrace \#2}

Charcoal from Santa Barbara Co, $19 \mathrm{~km} \mathrm{~W}$ of Gaviota Beach and $2 \mathrm{~km}$ E of Point Conception (34 $27^{\prime} 17^{\prime \prime} \mathrm{N}, 120^{\circ} 24^{\prime} 37^{\prime \prime} \mathrm{W}$ ), from Beach Fault terrace sediments comprised largely of continental alluvial fan deposits. Coll 1980 by D L. Johnson and T K Rickwell; subm by D L Johnson. 


\section{ISGS-721. Running Spring,}

San Migule Island SMI-251b

$\delta^{13} C=-24.4 \%$

Organic soil from Santa Barbara Co, $56 \mathrm{~km}$ WSW of Santa Barbara $\left(34^{\circ}\right.$ $02^{\prime} 44^{\prime \prime} \mathrm{N}, 122^{\circ} 25^{\prime} 34^{\prime \prime} \mathrm{W}$ ), from buried colluvial soil, $2.9 \mathrm{~m}$ below surface. Coll 1978 by D L Johnson and M L Barnhardt; subm by D L Johnson. Comment (DLJ): date is consistent with its stratigraphic position. Samples coll ca $1.2 \mathrm{~m}$ above this horizon dated $16,520 \pm 150 \mathrm{BP}$ and 15,630 $\pm 460 \mathrm{BP}$, respectively (ISGS-518, -525: R, 1981, v 23, p 377). Both samples indicate that episodes of fire occurred during full glacial time, and that Mammuthus exilis was then present on island.

\section{ISGS-725. Canada Verde uppermost $\quad 650 \pm 70$ buried soil SRI-16 \\ $\delta^{13} C=-26.2 \%$}

Soil from Santa Barbara Co, ca $60 \mathrm{~km}$ WSW of Santa Barbara $\left(34^{\circ} 00^{\prime}\right.$ $28^{\prime \prime} \mathrm{N}, 120^{\circ} 06^{\prime} 04^{\prime \prime} \mathrm{W}$ ), from uppermost buried soil in alluvial fill of Canada Verde assoc with shell midden material. Coll 1978 and subm by D L Johnson. Comment (DLJ): date is mean residence time for organic carbon in uppermost buried soil. Date shows that end of alluviation and onset of stream entrenchment began in very late Holocene, possibly during early historic period.

\section{ISGS-768. La Vista \#3}

$9960 \pm 200$ $\delta^{13} \mathrm{C}=-26.9 \%$

Organic material from Ventura Co, $3 \mathrm{~km} \mathrm{SW}$ of Ojai $\left(34^{\circ} 25^{\prime} 28^{\prime \prime} \mathrm{N}\right.$, $119^{\circ} 16^{\prime} 10^{\prime \prime} \mathrm{W}$ ), from interface between buried soil and overlying alluvium. Coll 1978 by D L Johnson and Mike Clark; subm by D L Johnson. Comment (DLJ): date marks time of burial of Oakview terrace paleosol at this site, and also marks time of faulting of terrace upon which cities of Oakview and, in part, Ojai are built.

\section{ISGS-774. Fossil Forest, SMI}

$\mathbf{2 7 0} \pm \mathbf{8 0}$

Organic material from Santa Barbara Co, midway between San Miguel Hill and Green Mt, San Miguel I., Santa Barbara (34 02' $16^{\prime \prime} \mathrm{N}, 120^{\circ} 22^{\prime}$ $30^{\prime \prime} \mathrm{W}$ ), from interiors of exhumed calcified plants (rhizoconcretions) in fossil forest exposed in wind-eroded eolianite dune. Coll 1976 by D L Johnson and D Muhs; subm by D L Johnson. Comment (DLJ): sample was expected either to be between 18,000 and 30,000 BP or to be modern. Young age fits neither assumption, but indicates that either (1) organic interiors of rhizoconcretions have been contaminated with plant roots growing into them from above, or (2) that some of rhizoconcretions are not old and may have formed around modern roots growing downward into colianite.

\section{ISGS-799. Oakview Terrace \#2}

Charcoal from Ventura Co, ca $0.25 \mathrm{~km} \mathrm{~S}$ of Oakview (34 23' $24^{\prime \prime}, 119^{\circ}$ $18^{\prime} 02^{\prime \prime} \mathrm{W}$ ), from fine-grained river alluvium, $8.3 \mathrm{~m}$ below Oakview terrace 
surface. Coll 1980 by D J Johnson and R K Rockwell; subm by D L Johnson. Comment (DLJ): date confirms 39,360 $\pm 2610 \mathrm{BP}$, previously determined by Univ of Washington for initial sedimentation of Oakview terrace. It is also concordant with younger date, ISGS-768: $9960 \pm 200 \mathrm{BP}$, on alluvium which overlies Oakview surface at La Vista \#3.

\section{Upper Sauces Canyon Fire area series}

Charcoal from Santa Barbara Co, $50 \mathrm{~km}$ SSW of Santa Barbara $\left(34^{\circ} 00^{\prime}\right.$ $31^{\prime \prime} \mathrm{N}, 119^{\circ} 52^{\prime} 00^{\prime \prime} \mathrm{W}$ ). Coll 1981 by M Glassow and D L Johnson; subm by D L Johnson.

\section{ISGS-876. SCI-16, Fire Area B}

From $90 \mathrm{~cm}$ below surface in alluvium.

ISGS-877. SCI-15, Fire Area A

$$
\begin{array}{r}
12,760 \pm 180 \\
\delta^{13} C=-24.9 \%
\end{array}
$$

$$
13,110 \pm 120
$$

$\delta^{13} \mathrm{C}=-22.0 \%$

From contact of residual soil developed in weathered bedrock and overlying alluvium in upper Sauces Canyon.

\section{Lower Sauces Canyon fossil logs series}

Fossil wood from Santa Barbara Co, $50 \mathrm{~km} \mathrm{SW}$ of Santa Barbara (34 ${ }^{\circ}$ $00^{\prime} 42^{\prime \prime} \mathrm{N}, 119^{\circ} 52^{\prime} 30^{\prime \prime} \mathrm{W}$ ), from floor of lower Canada de Los Sauces in alluvium. Coll 1981 by M Glassow and D L Johnson; subm by D L Johnson.

ISGS-878. SCI-18

ISGS-879. SCI-19

ISGS-907. SCI-20

ISGS-910. SCI-21

ISGS-915. SCI-23

ISGS-919. SCI-30

$$
\begin{array}{r}
12,920 \pm 140 \\
\delta^{13} C=-26.7 \% o \\
13,380 \pm \mathbf{8 0} \\
\delta^{13} C=-26.7 \% 0 \\
13,310 \pm \mathbf{1 0 0} \\
\delta^{13} C=-23.5 \% \circ
\end{array}
$$

$13,340 \pm 110$ $\delta^{13} C=-24.2 \%$

$12,630 \pm 100$ $\delta^{13} C=-24.2 \%$

$12,870 \pm 140$

$\delta^{13} C=-25.4 \%$ o

Missouri

\section{Brynjulfson Cave \# 1 series}

Extinct beaver bone from Boone Co, $19 \mathrm{~km} \mathrm{~S}$ of Columbia ( $38^{\circ} 51^{\prime} 07^{\prime \prime}$ $\left.\mathrm{N}, 92^{\circ} 16^{\prime} 50^{\prime \prime} \mathrm{W}\right)$, from ca $12 \mathrm{~m}$ length of cave fill. Coll 1962 by M G Mehl; subm by P W Parmalee, Univ Tennessee, Knoxville. 

ISGS-267A. Bone apatite
$21,570 \pm 510$
ISGS-267B. Bone collagen
$>29,800$

General Comment (PWP): collagen date (ISGS-267B) of $>29,800$ BP is consistent with two dates (ISGS-204A: >27,000 BP and ISGS-204B: 34,600 \pm $2100 \mathrm{BP}, \mathrm{R}, 1975$, v 17, p 172) obtained from extinct peccary from same cave. Degree of bone fossilization of these two species was similar and they may have been contemporaneous.

\section{Utah}

\section{Bald Mountain bog series}

Charcoal fragments from Summit Co, $44 \mathrm{~km} \mathrm{E} \mathrm{of} \mathrm{Kansas}\left(40^{\circ} 42^{\prime} 40^{\prime \prime}\right.$ $\mathrm{N}, 110^{\circ} 54^{\prime} 15^{\prime \prime} \mathrm{W}$ ). Coll 1980 by M L Barnhardt and P F Person; subm by M L. Barnhardt.

\section{ISGS-759. BMF-70}

$4320 \pm 120$

From charcoal layer, $70 \mathrm{~cm}$ below surface, on top of organic soil zone.

ISGS-763. BMF-83

$5050 \pm 130$

$\delta^{13} C=-23.5 \% 0$

From charcoal layer, $83 \mathrm{~cm}$ below surface at base of buried soil horizon.

General Comment (MLB): dates help establish rates of alpine meadow fm. ISGS-759 provides basal date for development of avalanche boulder tongues and other talus features utilized in alpine glacial chronology for area, whereas ISGS-763 dates beginning of depositional phase which may correlate with increased avalanche and talus activity assoc with post-Altithermal cooling.

\section{Bald Mountain W Meadow series}

Charcoal flasks from Summit Co, $43 \mathrm{~km} \mathrm{E}$ of Kansas $\left(40^{\circ} 41^{\prime} 30^{\prime \prime} \mathrm{N}\right.$, $110^{\circ} 55^{\prime} 10^{\prime \prime} \mathrm{W}$ ). Coll 1981 by M L Barnhardt and P F Person; subm by M L Barnhardt.

\section{ISGS-906. BMW-3-70}

From buried soil, 60 to $83 \mathrm{~cm}$ below surface.

ISGS-924. BMW-2-29
$6320 \pm 150$ $\delta^{13} C=-24.5 \%$

$4320 \pm 90$ $\delta^{13} \mathrm{C}=-24.3 \%$ surface.

From base of colluvial unit overlying ground moraine, ca $29 \mathrm{~cm}$ below 
Wisconsin

ISGS-1050. Waukesha Lime pit

$$
\begin{array}{r}
\mathbf{3 5 0 0} \pm \mathbf{7 0} \\
\delta^{13} C=-19.4 \%
\end{array}
$$

Organic clay from Waukesha Co, $1 \mathrm{~km} \mathrm{~N}$ of Waukesha $\left(88^{\circ} 12^{\prime} 44^{\prime \prime} \mathrm{N}\right.$, $\left.43^{\circ} 01^{\prime} 54^{\prime \prime} \mathrm{W}\right)$, from Beta horizon of buried soil in drumlin. Coll 1982 by L R Follmer and A K Hansel; subm by I. R Follmer. Comment (LRF): this material was thought to be either dead or modern. Results indicate that dated material was contaminated.

\section{ISGS-1061. Kewaunee South}

$11,700 \pm 100$

Wood from Kewaunee Co, S edge of Kewaunee $\left(44^{\circ} 26^{\prime} 50^{\prime \prime} \mathrm{N}, 87^{\circ} 30^{\prime}\right.$ $10^{\prime \prime} \mathrm{W}$ ), from top of buried black organic layer ranging from 5 to $13 \mathrm{~cm}$ thick. Coll 1981 and subm by A F Schneider, Univ Wisconsin - Parkside, Kenosha, Wisconsin. Comment (AFS): date confirms organic layer as Two Creek Forest Bed and overlying red till as Two River till.

\section{ISGS-1058. Two River South sand pit}

$11,910 \pm 120$

Wood from Manitowoc Co, N edge of Two Rivers $\left(44^{\circ} 09^{\prime} 58^{\prime \prime} \mathrm{N}, 87^{\circ}\right.$ $33^{\prime} 30^{\prime \prime} \mathrm{W}$ ), from red clayey till (Two River till). Coll 1968 by Paul Stoclting; subm by A F Schneider. Comment (AFS): date confirms post Two Creeks (Greatlakean) age of Two Rivers till at its type locality which has not previously been dated.

Michigan

\section{ISGS-948. Glenn Shores}

$$
\begin{aligned}
& >48,000 \\
& \delta^{13} \mathrm{C}=-27.0 \%
\end{aligned}
$$

Wood from Allegan Co, $2 \mathrm{~km} \mathrm{SW}$ of Glenn $\left(42^{\circ} 30.5^{\prime} \mathrm{N}, 86^{\circ} 15^{\prime} \mathrm{W}\right)$, from gravel underlain and overlain by clay till. Coll 1981 and subm by Greg Gephart, Dept Geol, Michigan State Univ.

\section{Alaska}

\section{ISGS-968. McBride Glacier Section}

$\mathbf{7 4 3 0} \pm \mathbf{7 0}$

Wood (spruce) from Glacier Bay National Park, $75 \mathrm{~km}$ NNW of Gustavus $\left(52^{\circ} 02^{\prime} 24^{\prime \prime} \mathrm{N}, 136^{\circ} 08^{\prime} 00^{\prime \prime} \mathrm{W}\right)$, from root of tree stump in breccia with thin soil. Coll 1981 and subm by R D Powell, Dept Geol, N Illinois Univ, DeKalb, Illinois. Comment (RDP): date agrees with other dates of Hypsithermal positions (McKenzie, 1976; Goldthwait, 1963, 1966). Farthest $\mathrm{N}$ date in Muir Inlet to be documented. 
Venezuela

\section{Old Beach Ridge Complex series}

Conch shells from Nueva Esparta $\left(10^{\circ} 58^{\prime}\right.$ to $59^{\prime} \mathrm{N}, 64^{\circ} 02^{\prime}$ to $\left.03^{\prime} \mathrm{W}\right)$. Coll 1978 to 1979 and subm by C S Alexander, Dept Geog, Univ Illinois.

ISGS-556. 3 Margarita

$510 \pm 70$

From $6 \mathrm{~km}$ WSW of La Guardia, from base of coquina pedestal, ca $0.5 \mathrm{~m}$ below surface.

ISGS-564. 2 Margarita surface.

From $2 \mathrm{~km} \mathrm{SW}$ of La Guardia, from beach ridge gravel ca $2 \mathrm{~m}$ below

ISGS-611. M-1979-1

$32,840 \pm 550$

From $0.5 \mathrm{~km}$ SW of La Guardia, from fine sand-silt-clay deposit ca $0.3 \mathrm{~m}$ below Coquina layer.

\section{REFERENCES}

Baker, F C, 1920, The life of the Pleistocene or glacial period: Illinois Univ Bull, v 17, no. 14 $476 \mathrm{p}$. v $64, \mathrm{p} 249$

Butzer, K W, 1977, Geomorphology of the lower Illinois Valley as a spatial-temporal contex for the Koster Archaic site: Illinois State Mus Repts Inv, no. 34.

Coleman, D D, 1973, Illinois State Geological Survey radiocarbon dates IV: Radiocarbon, v $15, \mathrm{p} 75-85$ $105-117$. States, in Porter Sangamon and Wisconsinan pedogenesis in the Midwestern United the US: Univ Minnesota Press, p 138-144.

Follmer, L R, McKay, E D, Lineback, J A and Gross, D L, 1979, Wisconsinan, Sangamonian, and Illinoian stratigraphy of Central Illinois: Friends of the Pleistocene, Midwest Sec, ann field conf, 26th, Illinois Geol Survey Guidebook 13, 134 p.

Frye, J C and Willman, H B, 1973, Wisconsinan climatic history interpreted from Lake Michigan lobe deposits and soils, in Black, $\mathrm{K} \mathrm{F}$ et al, eds, The Wisconsinan stage: Geol Soc America Mem 136, 135-152.

Gephart, G D, Managham, G W and Larson, G J, 1983, Stratigraphic evidence for a significant readvance of the Michigan ice lobe to the Kalamazoo Moraine-southwestern Michigan: $N$ central sec GSA abs, v 15, no. 4, p 261.

Goldthwait, R P, 1963, Dating the little ice age in Glacier Bay, Alaska: Internatl Geol Cong, 21 st, pt 27, p 27-46.

1966, Evidence from Alaskan glaciers of major climatic changes, Symposium on world climate, Proc: Royal Meteorol Soc, London, p 40-53.

Goldthwait, R P, Stewart, D P, Franzi, D A and Quinn, M J, 1981, Quaternary deposits of southwestern Ohio: GSA, 1981 Cincinnati Field Trip, no. 9, p 409-432.

Gooding, A M, 1975, The Sidney interstadial and late Wisconsinan history of Ohio and Indiana: Am Jour Sci, v 275, p 993-1011.

Hajic, E R, 1983, Shallow subsurface geology, geomorphology and limited cultural resource investigation of the Hillview Levee and Drainage District, Scott and Greene Counties, Illinois: US Army Corps Engineers, St Louis Dist Cultural Resource Management Rept, v 5 .

McKenzie, G D, 1976, Glacier fluctions in Glacier Bay, Alaska, in the past 11,000 years: Conf Sci Research Natl Parks, 1st, Proc, v II, p 809-813.

Springer, J W and Flemal, R C, 1981, Paleontological and geological results from two fossil proboscidean finds in Northern Illinois: Illinois State Acad Sci Trans, v 74, p 87-99. 
Wiant, M D, Hajic, E R and Styles, T R, 1983, Napoleon Hollow and Koster site stratigraphy: Implications for Holocene landscape evolution and studies of Archaic period settlement patterns in the lower Illinois R valley, in Phillips, J L and Brown, J A, eds, Archaic hunters and gatherers in the American Midwest; New York Academic Press, p 147-164

Willman, H B and Frye, J C, 1970, Pleistocene stratigraphy of Illinois: Illinois State Geol Survey Bull 94, $204 \mathrm{p}$. 